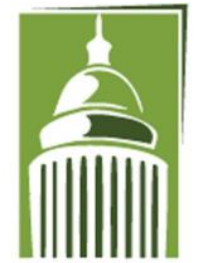

ARF

\section{Global Proceedings Repository \\ American Research Foundation}

ISSN 2476-017X

Available online at http://proceedings.sriweb.org

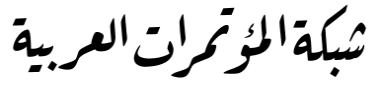

http://arab.kmshare.net/

The $12^{\text {th }}$ International Scientific Conference

Under the Title

"Innovative human, social, natural research, our vision for a prosperous economy and a better future by 2030"

$$
\begin{aligned}
& \text { المؤتمر العلمي الدولي الثاني عشر } \\
& \text { تحت عنوان }
\end{aligned}
$$

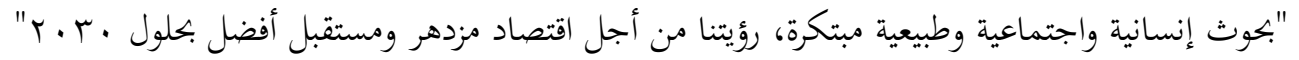

$$
\begin{aligned}
& \text { 29-30 يوليو } 2021 \text { - اسطنبول - تركيا } \\
& \text { http://kmshare.net/isac2021/ }
\end{aligned}
$$

\title{
The Role of Green Infrastructure in Achieving Socio-Spatial Dimensions in Housing Sustainability
}

\author{
Hoshyar Qadir Rasul ${ }^{\text {a }}$, Khuncha Fadhil Abdalqadir ${ }^{\text {b }}$, Sarko Hassan Sleman ${ }^{\text {c }}$ \\ ${ }^{a}$ Tishk International University, Sulaimanyiah, KRG - Iraq \\ hoshyar.rasul@tiu.edu.iq \\ ${ }^{\mathrm{b}}$ Kurdistan center for strategic studies \\ khuncha.fadhil@spu.edu.iq \\ ${ }^{\mathrm{c}}$ Tishk International University, Sulaimanyiah, KRG - Iraq \\ sarko.sleman@tiu.edu.iq
}

\begin{abstract}
Planning sustainable communities is a complex process that addresses the key areas of equitable economic, environmental and social sustainability. Nowadays the sustainable communities became the core objective in the view of building new world facing the multi and various challenges. Socio-spatial dimension represents greenspace networks integration into new development. Protecting and enhancing the existing physical assets are the pillars to achieve this goal.

Green infrastructure is a new concept of planning and design that consists primarily of a hybrid hydrological / drainage network, complementing and linking existing green areas with built-in infrastructure that provides ecological functions. Green infrastructure plans apply the basic principles of landscape ecology as well as
\end{abstract}




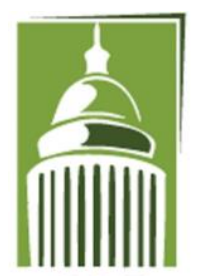

ARF

\section{Global Proceedings Repository \\ American Research Foundation}

ISSN 2476-017X

Available online at http://proceedings.sriweb.org

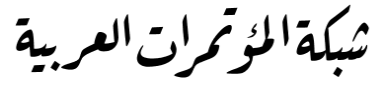

http://arab.kmshare.net/

appropriate solutions for roofing and shading in urban environments, specifically: a multi-scale approach with a clear attention to the pattern, social and spatial relationships, and emphasis on social and environmental interactions.

This research focuses on the socio-spatial planning communities in the view point of sustainability, analyzing previous studies, models and applications that illustrate possible spatial configurations of the green infrastructure to support and strengthen social relations with the physical side of the built environment, especially in residential neighbourhoods. The study presents theoretical models to understanding the social sustainability and guidelines for sympathetic the green infrastructure and its impact on achieving socio-spatial sustainability, taking (Sulaimaniyah Heights Residential Complex) in Sulaimaniyah city as a case study of one of the housing complexes that is still under construction, following the analytical quantitative approach methodology. The results show the importance of green infrastructure (GI) to obtain social sustainability through the use of green infrastructure as a tool to achieve socio-spatial sustainability in housing projects in areas with moderate climatic conditions.

Keywords: Social Sustainability, Green Infrastructure, Sustainable Housing Complex, Socio-Spatial Sustainability.

\section{Introduction}

During the last twenty years, Social sustainability has gained more importance, being used to assess sustainability performance of different components of housing and urban planning. Social sustainability indicators have gained more attention because of concerns with housing complex investments in both developed and developing countries. illustrating the possible impacts (both negative and positive) for the social sustainability on the housing projects and applying them helped to adding the sustainable initiatives in the housing and urban projects at the national, regional and local level, and achieving better quality of life applying sustainable planning strategies in order to promote sustainable goals in the complex housing projects (Haider et al., 2018). Any effort to plan the urban residential environment through housing decisions without a conscious understanding of the environment, the human being and the nature of the interaction between them transforming it in the way of social life and its interaction with the spatial activities to enhance the social relationships between the inhabitance will become mere attempts to be immature. Human beings are related to the environment, especially the residential, with a natural, reciprocal relationship in the effect that determines the shape of his life, the control of his presence in it, his behavior towards the direction of others, human shapes his environment and then the environment returns to form it (McKenzie, 2004) 


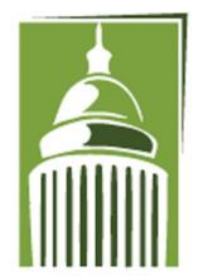

AR F

\section{Global Proceedings Repository \\ American Research Foundation}

ISSN 2476-017X

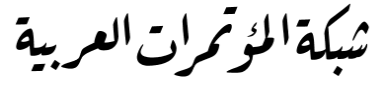

http://arab.kmshare.net/

Available online at http://proceedings.sriweb.org

The sustainable urban development aims to raise the standard of living, economic growth rates, and preserve the environment and natural resources to meet the needs of present and future generations, realizing social sustainability and justice. These can be obtained through applying the sustainability principles through the urban elements which are: green fabric, motion systems, social facilities and economy (de Roo, 2017).

Sustainable housing has the potential to produce good quality housing at a price that is affordable both in the short and long term. Thus, sustainable housing must aim at economic, social and environmental sustainability from planning to implementation phase and at the same time result in housing that is affordable, accessible and environmentally less damaging (Morelli, 2011). Therefore; Social sustainability occurs when the formal and informal processes, systems, structures and relationships actively support the capacity of current and future generations to create healthy and livable communities (Haughton and Hunter, 1994).

\section{Environmental sustainability}

More specifically, environmental sustainability could be defined as; a condition of balance, resilience, and interconnectedness that allows human society to satisfy its needs while neither exceeding the capacity of its supporting ecosystems to continue to regenerate the services necessary to meet those needs nor by our actions diminishing biological diversity (Morelli, 2011).

\subsection{Social sustainability}

According to McKenzie (2004), The social sustainability is "aspirational and visionary statements by which the following conditions may be achieved: Equity (the community provides equitable opportunities and outcomes for all its Members). Diversity: the community promotes and encourages diversity. Interconnectedness: the community provides processes, systems and structures that promote connectedness within and outside the community at the formal, informal and institutional level. Quality of life: the community ensures that basic needs met and fosters a good quality of life for all members at the individual, group and community level. Democracy and governance: the community provides democratic processes and open and accountable governance structures" (McKenzie, 2004, p: 18).

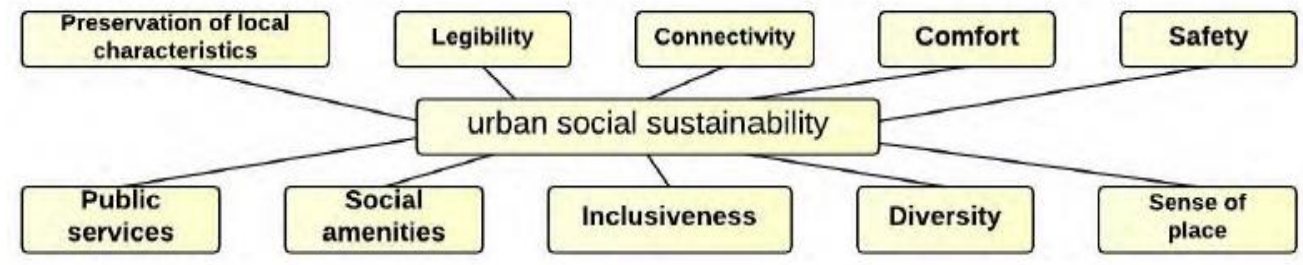

Fig. 1 significant factors affecting social sustainability of the residential areas and complex (Ghahramanpouri et al., 2015). 


\section{Global Proceedings Repository \\ American Research Foundation}

ISSN 2476-017X

Available online at http://proceedings.sriweb.org

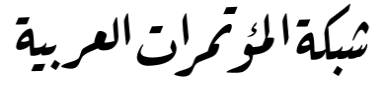

http://arab.kmshare.net/ AR F

On the residential zones and neighborhood level, social sustainability is about people quality of life, now and in the future.it describes the extent to which a neighborhood supports individual and collective well-being. Social sustainability combines design of the physical environment with a focused on how the people who live in and use a space relate to each other and function as a community (Kramer, 2014).

\subsection{Socio- spatial sustainability}

It is mean increasing the integration between the social community and the spatial sustainability (environmental sustainability) in the living zones, which is one of the main elements to achieve social sustainability (Kramer, 2014). Green areas, open spaces and walking zones have a high potential contribute the sustainability through the interactions of people, the place, and nature. Socio-spatial sustainability have already made considerable progress towards a more general understanding of the relevance of spatial solutions on the social spaces and activities to increase the social sustainability (Erdiaw-Kwasie, \& Basson, 2017). Incorporating the societies and economies into a sustainable environment analyses, require a broader framework for thinking about spatial elements to achieve it. In this stage, the role of spatial sustainability tools and concepts appear, such as the gray infrastructure or the newer one which is called green infrastructure (Erdiaw-Kwasie, \& Basson, 2017).

\subsection{Green infrastructure (GI)}

Green infrastructure proposes a modern method to the conceptualization and supervision of landscape, open spaces and green areas resources. It has developed quickly in the UK, Europe and North America as a consequence of the opportunities it has provided in gathering the social, economic and ecological challenges of spatial design (Mell, 2010). It is an integral component of sustainable communities primarily because it can help communities protect the environment and human health while providing other social and economic benefits (Kramer, 2014). Furthermore; Green Infrastructure states to ecological systems, both natural and engineered, that performance as living infrastructure. Green Infrastructure features are planned and managed primarily for storm-water control, but also exhibit social, economic and environmental benefits and finally it is an innovation for reaching a better quality of life (Brears, 2018). 


\section{Global Proceedings Repository \\ American Research Foundation}

ISSN 2476-017X

Available online at http://proceedings.sriweb.org

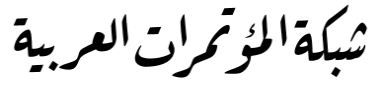

http://arab.kmshare.net/

According to Kramer (2014), there are many strategies clarify how green infrastructure can improve social sustainability and sustainable' methods to obtain an extensive range of aims, including to:

i.Preserve and reestablish open space, critical environmental areas and natural prettiness .

ii. Create community gardens, parks, and other public green spaces.

iii. Direct development toward existing communities .

iv. Create compact, mixed-use development.

v. Build neighborhood streets and trails that encourage walking and biking .

vi. Cultivate communities with a strong sense of place .

vii. Promote green building practices.

\section{Literature Review:}

Sustainability has turned into penetrating aim of housing and urban planning throughout the most recent decades (Ghahramanpouri et al., 2015). A mid the three piles of sustainability dimensions, preference have been given to the economic and environmental dimensions, while social sustainability have been greatly forgotten and displayed as a social connotation for environmental dimension (Ghahramanpouri et al., 2015). However, there are many studies that tried to determine the effective factors that reflect the social sustainability in the urban planning field. Ghahramanpouri et al (2015) had examined some factors of social sustainability through a study carried out on a neighborhood housing unit in a Southeastern Asian country (Kuala Lumpur) through the social sustainable behaviors in a housing congregation during a questionnaire method on 227 users for the housing project. This study determined nine social sustainability factors including: accessibility, house quality, human culture, participation, adaptability, legibility, place attachment, economic and road amenity had been extracted and concluded that these factors can be applied by urban planners and housing policies for creating more successful decisions to implement social sustainability as a main agent for achieving sustainable planning.

While Bacon et al. (2012) found out that social sustainability can depict the extent to the level that a neighborhood encourage the community and individual well-being. The study explained that social sustainability is a harvesting model of the physical environment and concentrate on how human use and live in the spaces, and also operate as a community by achieving fair infrastructures to brace the culture and social life, human opportunities to engage it, and create a chance to develop the community and the place together. They dedicated the connection between the open spaces, green areas, and social-commercial centers as the nucleus of the most sustainability in the housing aspects (Bacon et al., 2012). 


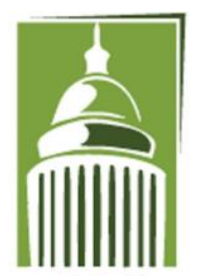

ARF

\section{Global Proceedings Repository \\ American Research Foundation}

ISSN 2476-017X

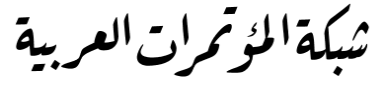

http://arab.kmshare.net/

Available online at http://proceedings.sriweb.org

Continuously, (Tawfiq, 2015) on the social sustainability and its relation with the spatial dimension in a residential complex showed that there is a dialectical relationship between the socio-spatial sustainability and the spatial organization. Through a spatial survey for Jihad neighborhood in Baghdad city depending on questionnaire method on random samples, Tawfiq ( 2015 ) limited the social sustainability indicators in the residential complex in many factors which are; 1 - social relation indicators within the residential complex itsel. 2- social homogeneity 3- Social interaction 4- Design aspect indicators, 5- Special organization indicator, which means the area where the individuals or families living in the complex meet. 6- Openness indicator, this is related to the adjacent areas of the housing complex. 7- Clarity and accessibility indicator. 8Space organization indicator, which is a strong magnet and attraction to the social behaviors.

Integrating the green infrastructure behind the gray infrastructure as a spatial-social communication in the housing complexes is another example to apply the social sustainability in it. Most contemporary urban GI efforts in the United States are small, individual projects rather than integrated efforts at the community level, but they have shown positive effects, encouraging the government to draft laws to encourage their application (Young, 2011). According to Young (2011), and supporting from the United States Environmental Protection Agency / US EPA, the GI essential elements that could apply it in a residential area where the spatial-social sustainability should interact concluded as:

I. Conservation design-maximal space, site and building Design.

II. Biodiversity.

III. Downspout disconnection.

IV. Evapotranspiration.

V. Low impact development (LID).

VI. Leadership in energy and environmental design (LEED).

VII. Smart growth.

VIII. Sustainable infrastructure.

IX. Urban heat landmass effect.

Last but not least, a deep clarification research done by (MacAdam, 2012) on the Southwestern neighborhoods in Tucson, Arizona/ USA. MacAdam (2012) defined GI elements (which is also called lowimpact development [LID]), as the use of living systems in a constructed way to supply environmental services, like storm water filtering, capturing, creating wildlife habit, shade provide, and ground water recharging. MacAdam (2012) clarified a common strategy to apply GI as a general concept in any neighborhood, which are:

- Rain gardens that capture storm water in rights of way, streets, and parking lots (often utilizing carb cuts or cores)

- Downs part disconnection and rain gardens or residential properties to harvest rainwater.

- Removal or reduction of hardscape, such as concrete or asphalt.

- Restoration of riparian buffers, green ways, and wild life corridors .

- Creation of neighborhood mini-parks, featuring rain gardens and native landscaping. 


\section{Global Proceedings Repository \\ American Research Foundation}

ISSN 2476-017X

Available online at http://proceedings.sriweb.org

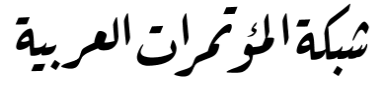

http://arab.kmshare.net/

AR F

MacAdam (2012) mentioned the above approaches; so the basic water harvesting is followed tenet of slowing, spread it, and sink it. Collecting water from where it falls and grow trees and plants was all mentioned by MacAdam (2012), this made storm water as a resource rather than a nuisance .

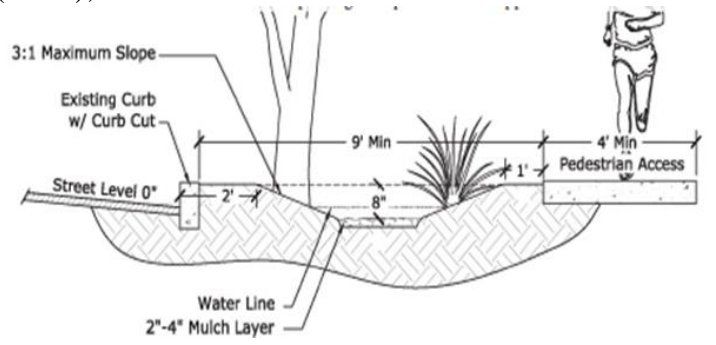

Fig. 2 Exemplary cross-section of a basin with sloping sides, showing typical setbacks for a site on a residential street with on-street parking (MacAdam, 2012)

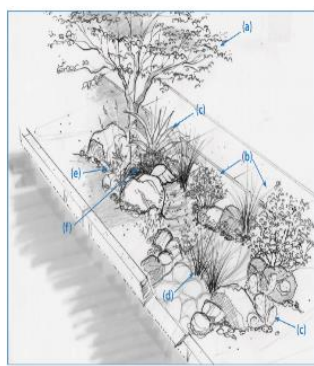

Fig. 3 Suitable positions for placement plants in a green infrastructure practice (MacAdam, 2012)

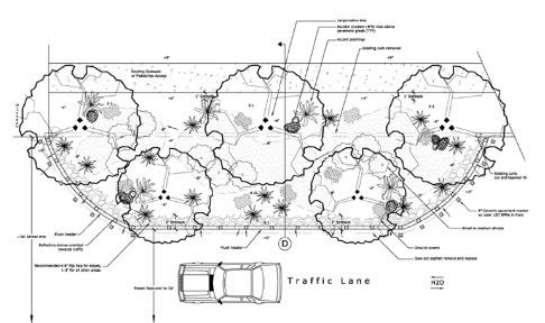

Fig. 4 Street width reduction,

(MacAdam, 2012).

The above mentioned and discussed articles show that they focused mainly either on the social sustainability, the effects of the spatial activities on the housing complex, or on the application of the green infrastructure (GI) on the housing generally. But what they haven't quite researched or understood yet is how the housing projects achieve social sustainability depending on the improvement of the socio-spatial activities in the housing complex projects, using the green infrastructure (GI) besides the gray infrastructure as a tool to access the social objectives and raise the performance of the social sustainability. That is the gap that this paper would like to focus on it.

\section{GI application:}

To apply the green infrastructure as an element to achieve socio-spatial sustainability, and according to the questionnaire result with the site analyzing. The implication of green infrastructure play a big role to obtain spatial sustainability to minimize the negative effect of the ultra-amount of rainfall which nowadays the Sulaimaniyah city suffer from unexpected rain fall and its high amount. As the Sulaimaniyah Height's constructed company (Qaiwan Group Company) explained that the Sulaimaniyah Heights Residential 


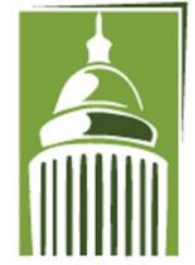

ARF

\section{Global Proceedings Repository}

American Research Foundation

ISSN 2476-017X

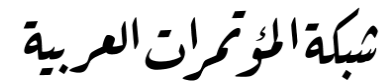

http://arab.kmshare.net/

Available online at http://proceedings.sriweb.org

complex designed to bearing a standard ratio of rainfall, but not the new rainfall phenomena, the maximum time that the rain water should flow through both the rain water drainage inlets and the natural absorption of the green spaces must be maximum 20 minutes.

The design for the rainfall absorption through both the natural absorbing of the soil and the designed inlets (rain water drainage) according to the Sulaimaniyah weather directorate is 124.8 millimeter per 24 hours) but according to the new researches done by Sulaimaniyah weather directorate it should design according to (185 millimeter per 24 hours) that explained the negative effects of the new rainfall's occurrences because it needs new solution to extend the absorption process. Generally; for calculating the rainfall amount depending on the below equation:

The amount of rain falls in cube meter (volume $\mathrm{Q})=\mathrm{R} * \mathrm{~A}$

$\mathrm{R}$ : rainfalls amount / meter (Standard according to the Weather Directory)

$\mathrm{A}=$ the area Falls on / square meter

\subsection{Eco block Module}

Infiltration modules, storm water management, and rainfall gathering. Technics, modules and technologies are compatible in this domain. So, might be applied easily which they are available, eco-friendly, sustain and resilience in the same time. For instance, Eco block module have three times the storage volume of a standard gravel infiltration ditch. Two modules therefore take the place of around $1300 \mathrm{~kg}(1,4 \mathrm{tons})$ of gravel or a 50m (164') drainage pipe. (https://www.graf-water.com/fileadmin/media/Katalog_V36_EN.pdf)
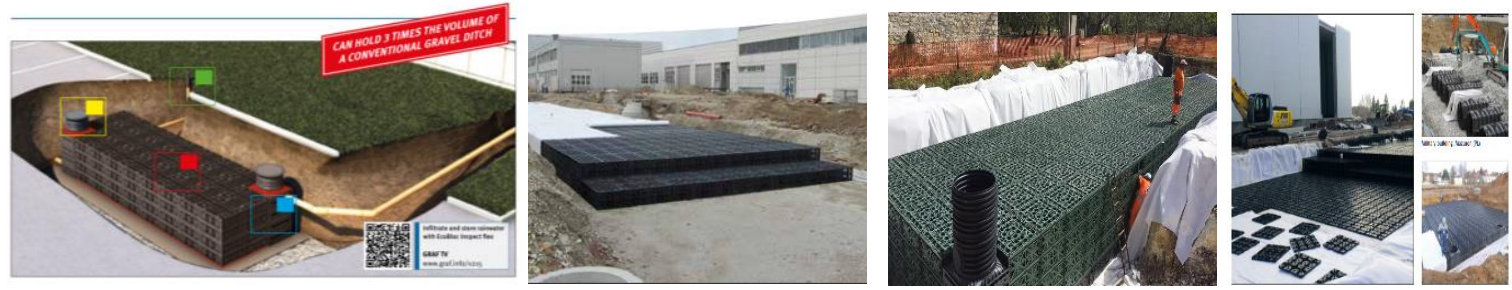

Fig. 5 Geosynthetic systems for both streets and landscapes (https://www.graf-water.com/).

Catching some indicators found out from literature review and related to Socio-Spatial Susainability, which are (social sustainability, spatial sustainability, and the application of green infrastructure) as listed in the table below;

Table 1 Socio-spatial sustainability indicators (by Researchers)

\begin{tabular}{|c|c|c|c|}
\hline & \multicolumn{3}{|c|}{ Indicators } \\
\hline \multirow{2}{*}{1} & \multirow{2}{*}{ - Social Sustainability } & - The social relations indicators & $\begin{array}{l}\text { - Social inclusion and coherence } \\
\text { - Quality of life }\end{array}$ \\
\hline & & - Social interaction & $\begin{array}{l}\text { - Interaction between the individuals } \\
\text { - Equity (homogeneity in the social } \\
\text { level). }\end{array}$ \\
\hline
\end{tabular}


ISSN 2476-017X

Available online at http://proceedings.sriweb.org

\begin{tabular}{|c|c|c|c|}
\hline & & & - Spatial activities \\
\hline & & - Future focus & $\begin{array}{l}\text { - Valuing and protecting of culture } \\
\text { for future generations } \\
\text { - Community thriving guaranteed for } \\
\text { next generations }\end{array}$ \\
\hline & & $\begin{array}{l}\text { - spatial design's impact on social } \\
\text { relations }\end{array}$ & $\begin{array}{l}\text { - Pride, sense of place and identity } \\
\text { - Society perceptions of the spatial } \\
\text { place }\end{array}$ \\
\hline 2 & - Socio-Spatial Sustainability & $\begin{array}{l}\text { - Socially consistent and physically } \\
\text { combined to spatial unit }\end{array}$ & $\begin{array}{l}\text { - Social cohabitation } \\
\text { - Spatially integrate } \\
\text { - How people live and use a space } \\
\text { - Scope for the place and the } \\
\text { - Certain places occurring frequent } \\
\text { gathering } \\
\text { - Safety } \\
\text { - Social amenities } \\
\text { - Connectivity } \\
\text { - Public services } \\
\text { - Legibility } \\
\text { - Place attachment }\end{array}$ \\
\hline & & - Spatial objectives & $\begin{array}{l}\text { - Efficient built-up development } \\
\text { - Quality of life } \\
\text { - Conservation with the environment }\end{array}$ \\
\hline 3 & - Spatial Sustainability & $\begin{array}{l}\text { - Sustainable design and } \\
\text { implementation }\end{array}$ & $\begin{array}{l}\text { - Application of green infrastructure } \\
\text { - Develop sustainable strategies } \\
\text { - Develop method for ecological } \\
\text { conservation }\end{array}$ \\
\hline
\end{tabular}

\section{Research question}

Do through applying the green infrastructures (GI) elements -as a tool- can to raise the socio-spatial activities performance in the residential areas, and achieve the social sustainability's aim between the inhabitances? 


\section{Global Proceedings Repository \\ American Research Foundation}

ISSN 2476-017X

Available online at http://proceedings.sriweb.org

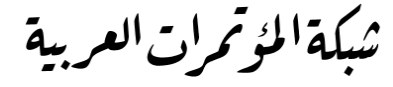

http://arab.kmshare.net/

ARF

\subsection{Objectives}

1. Demonstrate the importance of linking social sustainability and spatial sustainability through activating the role of green infrastructure, and its importance in the new housing complexes planning, and thus to achieve social sustainability that is no longer considered in the new housing complexes nowadays.

2. Systematically implement the green infrastructure in the residential projects from the beginning stages of design and constructing to be a common sustainable tool.

\subsection{Methodology}

For answering the research question and obtaining the research objectives, the research will focus on one of the housing projects which is Sulaimaniyah Heights Residential Complex project to evaluate and analyze the socio-spatial sustainability and its implications on social community following systematical stages of the analytical quantitative methodology.

\section{Case - Study}

In Kurdistan region, because of the political changes that have taken place especially since 2006, the region has witnessed rapid changes in different aspects, including re-construction and emergence of Housing projects investments. These changes and urban developments in the Kurdistan region have led to reformulation and re-planning the urban master plan at the regional level in general and the cities level in particular, thus radical changes have been seen in housing policy to keep up with these developments and multi patterns of housing investments had appeared.

Sulaimaniyah City (which is taken as a case study) is not far from these developments and changes. Housing complexes have emerged greatly without taking in the consideration the principles of sustainability generally and the social sustainability particularly. This part of the paper deals with the field side studies as a complementary to the previous theoretical part which determined several indicators about the (socio-spatial sustainability) and the green infrastructure's elements to be a good information recourses for developing the survey field of the paper.

The main reason behind choosing the study area (Sulaimaniyah Heights Residential complex) see figures 6, 7, 8 and 13. The project is still under construction, the project has been constructed in (2011) and expect to be complete in (2025) which had built on (360 acres), contains (2284) housing units with a population approximately (11000 residents) with the supplement services, through three main constructing phases. Nowadays, the first phase had completed and it is also inhabited, so the social relationship between its residents can be studied and determine the extent of the social compatibility among them. If the spatial organization of the social activities has impacts on the social relationship, the result of this study can be applied on the next constructing phases of the complex. 


\section{Global Proceedings Repository \\ American Research Foundation}

ISSN 2476-017X

Available online at http://proceedings.sriweb.org

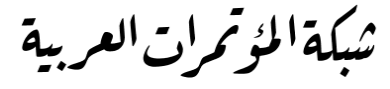

http://arab.kmshare.net/

Furthermore, this paper is not about a residential complex only, it is about a sector and this research's results can be expected on the sector level, because (Sulaimaniyah Heights Residential complex) according to (Urban Housing Standards Manual, 2010), which is provided by (State Commission of Housing- Ministry of Construction \& Housing in Iraq) can be classified as a sector residential zone (Urban Housing Standards Manual, 2010). The project located on the northern of Sulaimaniyah city close to Azmar and Goizha mountains (as shown in figure 6,7, and 8). It has a special topography that increase the problem size of achieving the social sustainability. in addition; it contain five spatial zones, the zone (1) is under construction, \% 72 is completed, \%21 of zone (2) and \%31 of zone (4), but zone (3) and zone (5) are still not constructed. Therefore; this paper focus on the zone (1), (2), and zone (4) as the most complete zones as shown in figure 8 .

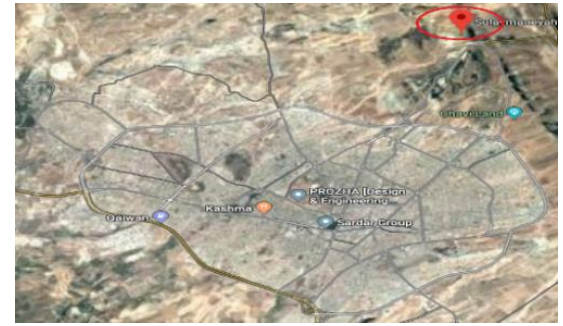

Fig. 6 Satellite image for Sulaimaniyah city

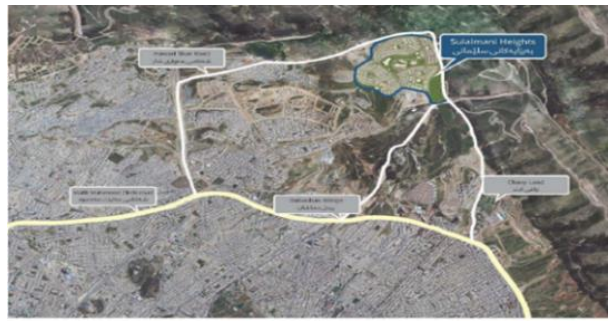

Fig. 7 Satellite image explained the location of the Fig. 8 Site plan project in the northern of Sulaimaniyah city (by Researchers)

\subsection{Data Collection}

A sample size of 30 households were taken within both zones of Sulaimaniyah Heights Residential complex which is mean $15 \%$ of the total families live in it, (since the inhabitants of the complex are 196 families nowadays, $11 \%$ of the total chosen selected samples were live in house units and $4 \%$ of chosen from the flat units). The sample selection were randomly selected within the predefined zones according to quasi experiment that tried approximately to cover equal distributions for a different zones in the project. The questionnaire type which was used is (Close-end Questionnaire) contains (23 questions concluded from the theoretical part of the paper). 


\section{Global Proceedings Repository \\ American Research Foundation}

ISSN 2476-017X
ARF

Available online at http://proceedings.sriweb.org

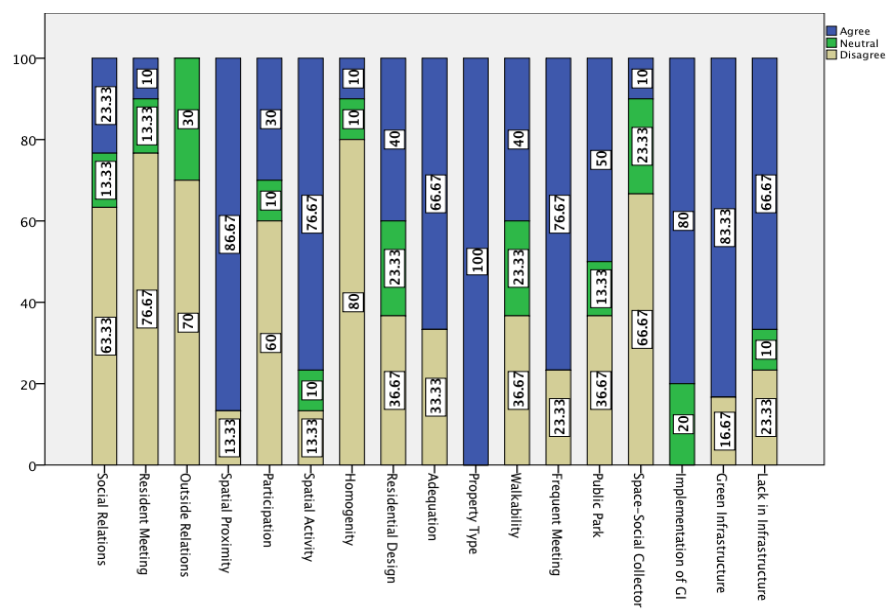

Fig. 9 Data collected and analyze by SPSS program (The indicators' specific Questionnaire).(by researchers)

\subsection{Results and discussion:}

The method tool and analyze was done by using the SPSS program (Statistical Package for the Social Sciences) (figure 9). Starting with social relations between the inhabitants in the complex as all, about $23.33 \%$ are arguing that the social relation is good (acceptable), which represent the social relation weakness which it is expected. This is because of the lack of residents' meeting in which the questionnaire displayed $76.6 \%$ of the inhabitants disagreed when they were asked about residents' frequently meeting with each other .

$40 \%$ of the participants were seeing the project to have a good walk from their house units to an open space or social activities. Although $86.7 \%$ of the residents agreed that spatial proximity is the major factor to increase social relations, but in Sulaimaniyah heights, the described points and having a shortage especially with the hard topography nature of the complex and makes the activities to be far from each other.

As an evidence for the previous points, $76.6 \%$ of the residents agreed with the presence of spatial activities and open spaces that help to make interaction with each other as explained in the figure 10. The social relation is not only weak inside the complex, there is lack of relation with outside of the complex, as described by $70 \%$ of the participants showed their disagreement for being in relation with in-city's neighborhood. Even $60 \%$ of the residents explained their difference in opinion for existing and social events that increase the interaction between the complex's residents.

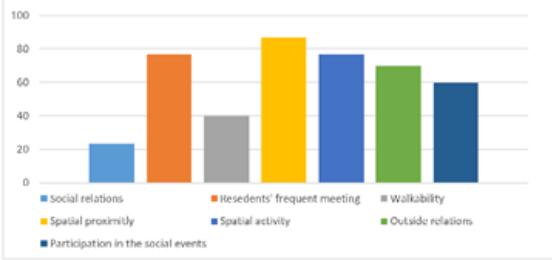

Fig. 10 


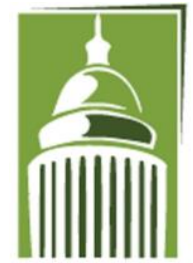

ARF

\section{Global Proceedings Repository}

American Research Foundation

ISSN 2476-017X

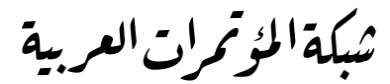

http://arab.kmshare.net/

Available online at http://proceedings.sriweb.org

During making the questionnaire, they described that the flat house units with their own open space might effect on the social relations between the inhabitance. Furthermore; $100 \%$ of the participants agreed that the horizontal house units are more socially connected than the apartment units. See figure 11.

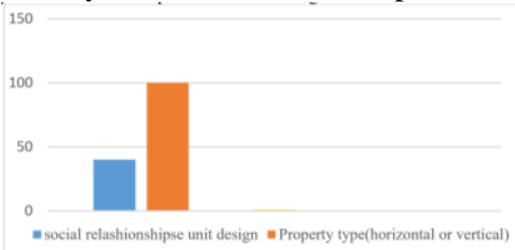

Fig. 11

$66.6 \%$ of the questionnaire participants were concurrent that the open space areas and the recreational zones are sufficient. For more explanation, the public park is a great, ethics, and attractive point in the complex, but they can only be found with a wear interaction within daily life. Only $50 \%$ of the participants agreed that the public park has a good characteristic for creating social interaction, because according to this questionnaire, it is far from the resident house units. Also many problems are in the walkways and the lack in shading elements that made them difficult to access it. See figure 12, 13.

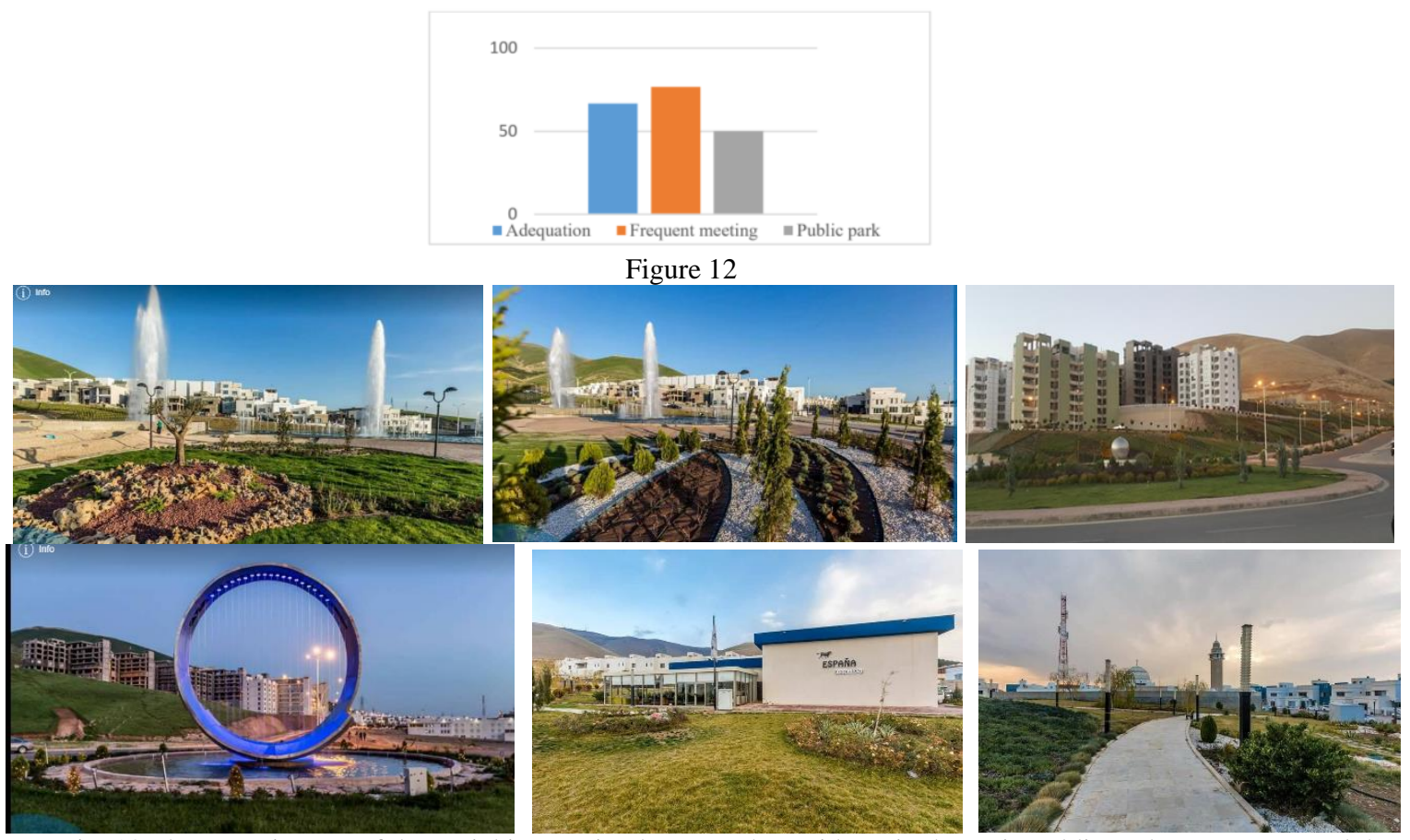

Fig. 13 The nonexistence of the social integration between the residents in the main public parks, restaurant and the mosque (by Researchers) 


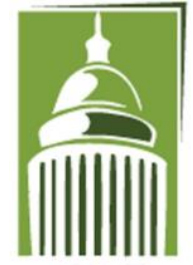

ARF

\section{Global Proceedings Repository \\ American Research Foundation}

ISSN 2476-017X

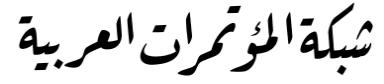

http://arab.kmshare.net/

Available online at http://proceedings.sriweb.org

During asking about spatial sustainability, $66.6 \%$ of the questionnaire participants disagreed on the quality of the open spaces and the walkways, this hamper the socio-spatial sustainability, and the poor design and planning perspectives, but inferior the infrastructure point of view after explaining the concepts of green infrastructure for the participants. $80 \%$ of them strongly agreed with the new idea because they believed that it can increase the social relationships through the complex. On account of the green infrastructure, this can solve the walkability and gathering in the open areas. $83.3 \%$ agreed to apply the green-infrastructure especially the project of Sulaimaniyah Heights residential complex that is still under construction and can implement the green infrastructures' tools behind the gray infrastructure. This is due to the $66 \%$ of the participants that fixed that to the lack of a sustainable infrastructure negatively impact the on the social activities. As shown in figure 14.

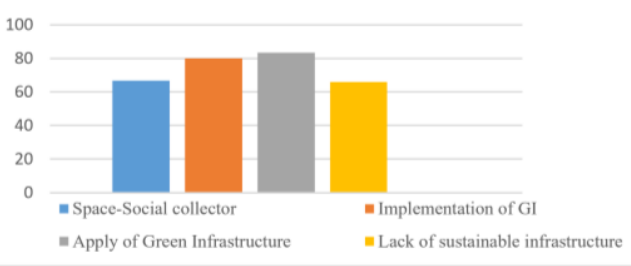

Figure 14

- The questionnaire clarified that the project have the enough amount of open spaces to cover the resident's need, but neglecting a few important points caused the use less of these spaces and impact negatively on the social relation between the inhabitance. According to the questionnaire, $75 \%$ of the resident especially the young families, explained that the open spaces do not have the important landscape furniture such as chairs, kids' games, and shades. In addition, it's important to focus on the location of the complex which have a harsh (tough) weather especially in winter which is so rainy, causes sometimes a raise in the rain water level on the streets and the pedestrian paths which hinders the movement of the pedestrian and the assembly of the inhabitance. Hence, the real importance of the green infrastructure GI and its application appears here to increase the ability to use public areas thus strengthen social relationships, achieving social sustainability, and a better quality of life.

- According to the formula (mentioned in item 4), calculating the rainfall amount for the green areas in 24 hours for each constructed zone in the complex according to the previous and last data of Directory of Sulaimaniyah meteorology; as shown in table 2:

Table 2

\begin{tabular}{|c|c|c|c|c|c|c|}
\hline $\begin{array}{l}\text { The } \\
\text { zone }\end{array}$ & The rain falls formula & $\begin{array}{l}\text { The } \\
\text { ainfalls } \\
\text { nount for } \\
\text { een areas } \\
\mathrm{m}^{3} \text { for } 24 \\
\text { hours }\end{array}$ & $\begin{array}{c}\text { The rain falls } \\
\text { amount in } \mathrm{m}^{3} \\
\text { should be absorbed } \\
\text { in } 20 \text { minutes( } 0.33 \\
\text { hour) according to } \\
\text { the construction } \\
\text { design }\end{array}$ & $\begin{array}{l}\text { The rain falls formula } \\
\text { according to the new } \\
\text { records } \\
\text { (Sulaimaniyah } \\
\text { Weather Directory) } \\
\text { (185ml in } 24 \text { hours) }\end{array}$ & \begin{tabular}{|} 
The rain falls \\
amount in $\mathrm{m}^{3}$ \\
should be \\
absorbed in 20 \\
minutes( 0.33 \\
hour) according \\
to the \\
construction \\
design due to the \\
new phenomena
\end{tabular} & $\begin{array}{l}\text { The rain falls } \\
\text { amount in } \mathrm{m}^{3} \\
\text { should be } \\
\text { absorbed in } 20 \\
\text { minutes( } 0.33 \\
\text { hour) according } \\
\text { to the new } \\
\text { records }\end{array}$ \\
\hline Zone 1 & $0.1248 \mathrm{~m} * 34000 \mathrm{~m}^{2}$ & 4243.2 & 58.93 & $0.185 \mathrm{~m} * 34000 \mathrm{~m}^{2}$ & 6290 & 86.49 \\
\hline
\end{tabular}




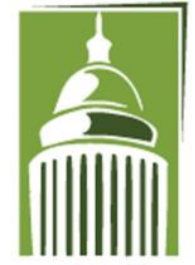

ARF

\section{Global Proceedings Repository}

American Research Foundation

ISSN 2476-017X

Available online at http://proceedings.sriweb.org

\begin{tabular}{|l|l|l|l|l|l|l|}
\hline Zone 2 & $0.1248 \mathrm{~m} * 53000 \mathrm{~m}^{2}$ & 6614.4 & 90.948 & $0.185 \mathrm{~m} * 53000 \mathrm{~m}^{2}$ & 9805 & 134.81 \\
\hline Zone 5 & $0.1248 \mathrm{~m} * 45000 \mathrm{~m}^{2}$ & 5616 & 77.22 & $0.185 \mathrm{~m} * 45000 \mathrm{~m}^{2}$ & 8325 & 114.47 \\
\hline
\end{tabular}

Due to the previous table and as illustrated through figure 15, it was founded that the rain fall water inlets (pipes' radius) should redesign them to accommodating the falling rain, this can be calculated according to this equations according to the open spaces (as shown in figure 15 which have a defect in draining or absorbing the rain fall :

$\mathrm{Q}=\mathrm{A} * \mathrm{U} \ldots$ For the pipes:

$\mathrm{Q}=\pi \mathrm{R}^{2} * \mathrm{U}$

$\mathrm{Q}=$ volume of the rain falls amount $\mathrm{m}^{3} / 24 \mathrm{~h}$

$\mathrm{R}=$ radius of the inlet pipes

$\mathrm{U}=$ velocity (according to a standard charts between $0.24-0.6 \mathrm{~m} / \mathrm{sec}$.)
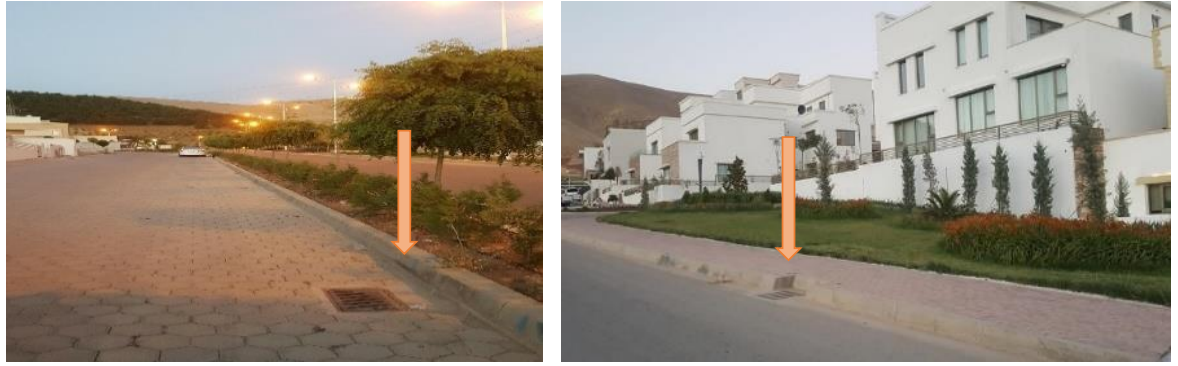

Fig. 15 Location of some rainfall drainage which have problems in there drain capacity also need to apply GI. (by Researchers)

\section{Conclusions:}

The term socio-spatial sustainability in the housing aspects is a new variable in the sustainability parts that has a quite relationship with each other to attain a sustainable environments that innovate a good quality of life. The social integration one of the most important elements of the social regulation (social sustainability) in the residential complexes to achieve the social relationships, so that realizing the social needs and desires. This point can reach through a better spatial distributions and applying the green infrastructure beside the gray infrastructure as a tool achieve climatically treatment for the (Sulaimaniyah Heights Residential Complex project), which has a vast problematic of the climate issue.

This paper found out a good solved and attractive space design, climatically treated, accessible walk ways, taking in to account its relevance to all age groups living in the complex, which formed a key points to get the socio-spatial sustainability goals in the residential complexes.

The green infrastructure is a sustainability method. It has a large effect on increasing the socio-spatial relations, thus a better integration between the residents that obtain a social sustainability, which its first aim is getting a better quality of life for each individual in the community. Consequently due to the constructing 


\section{Global Proceedings Repository \\ American Research Foundation}

ISSN 2476-017X

Available online at http://proceedings.sriweb.org

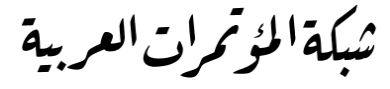

http://arab.kmshare.net/

ARF

process of the (Sulaimaniyah Heights Residential Complex), the green infrastructure can easily apply because the complex is still under construction. On the other hand; according to the questionnaire, the residents suffer from the lack in climatically solutions that cause a lack in the socio-spatial relations . Finally; In Sulaimaniyah Heights project when the green infrastructure would be applied, besides solving the rainfalls drainage inlets dimeters will take a great jump towards achieving social spatial sustainability that acquire the social sustainability.

\subsection{Recommendation:}

Taking in consideration the socio-spatial integrations due the residential complex's management to produce a socio-spatial events frequently to create a strong relationship between its inhabitants. Also, Applying green infrastructure's concept during constructing the residential complex generally and the open spaces with the green areas especially to improve the walkability and resident's gathering.

According to the discussions with the company who is responsible to construct of the Sulaimaniyah Heights Residential Complex project (Qaiwan Group), and as an alternative method to apply the Green infrastructure, and according to this papers results; this research recommend to use geosynthetic systems (Eco blocks module) figure 5 , which have many methods, modules and material types that can be used for constructing the roads, streets, landscapes and walkways, as an sustainable concepts for decreasing the rainfalls aggregations and reusing the collecting water after treat and re-filter it. This method is an economic treatment as a future solution forwards.

Finally, it is the governments duty to set up rules and legislations for the housing investment projects to inforce the investors to take the social integrations in the account at the projects design and cooperate the social aspects with the spatial elements, to achieve social sustainability that become an losing identity in the residential complex.

\section{References}

- Bacon, N., Cochrane, Douglas \& Woodcraft, S., 2012. Creating strong communities: how to measure the social sustainability of new housing developments, London: The Berkeley Group.

- Brears, R. C. (2018). Blue and Green Cities: The Role of Blue-Green Infrastructure in Managing Urban Water Resources. Springer.

- De Roo, G. (2017). Integrating city planning and environmental improvement: Practicable strategies for sustainable urban development. Routledge.

- Directorate of Sulaimanyiah Meteorology, (2018) 


\section{Global Proceedings Repository \\ American Research Foundation}

ISSN 2476-017X

Available online at http://proceedings.sriweb.org

- Erdiaw-Kwasie, M. O., \& Basson, M. (2017). Reimaging socio-spatial planning: Towards a synthesis between sense of place and social sustainability approaches. Planning Theory, 1473095217736793.

- Ghahramanpouri, A., Abdullah, A. S., Sedaghatnia, S., \& Lamit, H. (2015). Urban social sustainability contributing factors in Kuala Lumpur Streets. Procedia-Social and Behavioral Sciences, 201, 368-376.

- (https://www.graf-water.com/fileadmin/media/Katalog_V36_EN.pdf), (https://www.graf-water.com/).

- Haider, H., Hewage, K., Umer, A., Ruparathna, R., Chhipi-Shrestha, G., Culver, K., \& Sadiq, R.(2018) Sustainability assessment framework for small-sized urban neighbourhoods: An application of fuzzy synthetic evaluation. Sustainable cities and society, 36, 21-32.

- Haughton, G., \& Hunter, C. (1994). Sustainable cities, regional policy and development series 7. Regional Studies Association. London and Bristol, Pennsylvania.

- Kramer, M. (2014). Enhancing sustainable communities with green infrastructure. Office of Sustainable Communities, US Environmental Protection Agency: Washington, DC, USA, 66.

- MacAdam, J. M. (2012, October). Green Infrastructure for Southwestern Neighborhoods. Retrieved May 11, 2018, from Available electronically at: http://www.watershedmg.org/green-streets

- McKenzie, S. (2004). Social sustainability: towards some definitions.

- Mell, I. C. (2010). Green infrastructure: concepts, perceptions and its use in spatial planning.

- Morelli, J. (2011). Environmental Sustainability: A Definition for Environmental Professionals. Journal of Environmental Sustainability, 1(1), 1-10. doi:10.14448/jes.01.0002

- Republic of Iraq- Ministry of Construction\& Housing, (Urban Housing Standards Manual, 2010), P. 9

- Tawfiq, a (2015). The fundamentals of spatial social organization in the planning of residential complexes. Center for Urban and Regional Planning. University of Baghdad.

- Young, R. F. (2011). Planting the Living City. Journal of the American Planning Association, 77(4), 368-381. doi:10.1080/01944363.2011.616996 